\title{
Adını Koymak: Karşılaştırmalı Edebiyat
}

\begin{abstract}
Abdulfettah İMAMOĞLU*
Öz

Millî edebiyata alternatif bir fikir olarak ortaya çıkmasının ardından, on dokuzuncu yüzyılın ilk yarısında, bir disiplin olma gelişimi yaşayan ve akademik sahada ilk olarak, Fransa'da, "littérature étrangère" yani "yabancı edebiyat" adı ile kendini gösteren Karşılaştırmalı Edebiyat ile özdeşleştirilen ya da bu disiplini tanımlamak için önerilen ve hâlen önerilmekte olan birçok isim bulunmaktadır. Bunlar arasında, dünya edebiyatı, kapsayıcı ve öncül bir konsept olarak, en fazla ön plana çıkan kavram olmakla birlikte, "edebiyat tarihi”, "genel edebiyat tarihi”, "genel ve karşılaştırmalı edebiyat", "evrensel edebiyat" gibi adlandırmalar da bu listede yer almıştır. Bugüne gelindiğinde, bu araştırma sahasına dair hâlen bir isim birliği olmamakla beraber, akademik bağlamda, "karşılaştırmalı edebiyat" adı en yaygın kullanıma sahip olma niteliğini korumaktadır. Söz konusu isim çeşitliliğinin ele alınacağı bu makalede, edebiyat insanlarınca öne sürülmüş farklı yaklaşımlara da yer verilerek, yaklaşık iki yüzyıllık bir geçmişe sahip olan Karşılaştırmalı Edebiyat disiplininin adına dair tarihsel bir okuma yapılacak, bugünkü koşullar altında, bu disiplininin ismine yönelik terminolojik ve aynı zamanda güncel bir incelemede bulunulacaktır.
\end{abstract}

Anahtar Kelimeler: karşılaştırmalı edebiyat, dünya edebiyatı, edebiyat tarihi, yabancı edebiyat, evrensel edebiyat, terminolojik tartışmalar

*Dr., Eskişehir Osmangazi Üniversitesi, Eskişehir, Türkiye.

Elmek: aimamoglu@ogu.edu.tr

https://orcid.org/0000-0003-3509-066X

Gelis Tarihi / Received Date: 05.03.2020

Kabul Tarihi / Accepted Date: 24.06.2020 


\title{
Finding a name for it: Comparative Literature
}

\begin{abstract}
Following its appearance as an alternative idea to national literature, there have been many names suggested and still being offered to define or identify comparative literature, which started to develop as a discipline during the first half of the nineteenth century and made its first appearance in the academic field in France under the name of "littérature étrangère", or "foreign literature". Among these, along with "world literature", which, as an initial and general concept, seems to be the most prominent one, denominations such as "history of literature", "general history of literature", "general and comparative literature" or "universal literature" have taken place on this list. Even today, although there still isn't an accepted denomination, the term "comparative literature" is the most commonly used name in the academic context regarding this research field. In this article, where the so called diversity of names will be discussed, by including different approaches suggested buy men of letters, a historic study regarding Comparative Literature, which has about a two-hundred-year old history, will be done and, under today's circumstances, a terminological and an up-to-date study on the name of this discipline will be held.
\end{abstract}

Keywords: comparative literature, world literature, literary history, foreign literature, universal literature, terminological discussions 


\section{Extended Summary}

As a nineteenth century discipline, Comparative Literature has been derived from the idea of world literature that has been originated from the German term "Weltliteratur", deployed in a remarkable way by Goethe. Given its significant role to explain comparative literature, Weltliteratur will be taken, in the first chapter of this article, entitled "Weltliteratur and Beyond", as a starting point to demonstrate the historical evolution of comparative literature terminology. While it has been utilized by an influential German writer of nineteenth century to draw attention on the importance of discovering the Other that exists beyond borders, the term "world literature" is afterwards defined and redefined by a growing number of literary personalities representing different backgrounds and thus expanded its meaning compared to its early use. In relation with that state of continuing expansion, as it will be shown in the first chapter, literature itself has become likely to embrace a new definition in terms of its relation with other disciplines as well as with the notion of "culture" which contains, indeed, a wide connotation, with reference to notions like civilization, history, language and arts. As an impact of comparative literature, the concept of literature entered another stage by broadening its area of activity through the inclusion of links with a wide range of research spheres, namely, cinema, history or sociology, and becoming thus open to be configured in a perpetual way by a variety of factors and elements that will grow constantly in numbers. In the first chapter, the reader will discover how the notion of literature has been reconstructed with adjectives like "general", "comparative" or "international", and has been conceived in association with terms like philosophy, history and aesthetics.

As a consequence of the changing perspective regarding literature, a state of innovative conceptual trends in academic world is also noticeable. That is why, in the second chapter named "Academic Visibility: Past and Present", the perspective will be focused on the diversity of names that have been created to designate studies related to comparative literature. This second part will particu- 
larly point that, as it may be observed in the past, the current tendencies have been translated by different choices of names as a result of different approaches in terms of studying literature in a more inclusive, dynamic, international way. This is because the globalization affects all aspects of arts, literature appears to adapt itself, as well, into these new circumstances of the world in communication and interaction. That being said, in every single country, each academic tendency meets a necessity that defines the literary disposition and the artistic consideration in that country. In this respect, even if that kind of divergent situation may give the impression of disarray, it is in fact convenient to say that this very diversity of approaches are set to proceed towards the world literature ideal that promotes a republic of letters in which all languages and literatures could find an impartial place to be expressed, to be heard. So, as this paper intends for demonstrating it, comparative literature, thanks to its mission to create bridges between differences, takes the charge to make more plausible an atmosphere of interaction that would attain all forms of universal expression, all constituents of world culture.

By this article, it will be possible to present a large panorama of current academic tendencies evolved in multiple cultural geographies situated in different continents. With each example, it will be confirmed that comparative literature is mostly seen as a new and liberal manner to approach literature, by attempting to pass beyond traditional and national norms which may possess the potential to prevent the possibility of a communication between literatures, languages and cultures. In other terms, by presenting the complexity of definition which is related to a discipline generated by the term "world literature", a term employed as an alternative to the term "national literature" which was seen incomplete by the reason of new conditions of the world reality in the nineteenth century, this work will help to understand the comprehensive aspect of comparative literature through its capacity to provide a generous platform to contribute to the conception of literature as a whole universal human science. 


\section{Giriş}

On dokuzuncu yüzyılın ilk yarısında bir beşerî bilimler alanı olarak ortaya çıkan Karşılaştırmalı Edebiyat, bu tarihten beri kendine akademik sahada kalıcı bir yer edinmeye çalışmaktadır. Hâlen, sınırlarının nerede başlayıp nerede bittiği hususunda tartışmaların canlı olduğu bu disiplin, bu nedenle farklı tanımlara, yaklaşımlara, yorumlara ve eleştirilere maruz kalmaktadır. Karşılaştırmalı Edebiyatı kendi kültürel, politik ve sosyal şartlarına uyarlamaya çalışan coğrafyalar, bunu yaparken, söz konusu disiplini yeniden tanımlama yoluna gitmektedirler. Nitekim diğer beşerî bilim alanlarının aksine, Karşılaştırmalı Edebiyat isminin herkesçe benimsenmiş tek bir tanımı yoktur. Bir dünya edebiyatı projesi olarak var olmaya çalışan ve bu yüzden, her ulusal edebiyatın katkısı ile yeniden şekillenen bu disiplin, öte yandan, standart kurallara elverişli de görünmemektedir. Kültür, dil, zaman, coğrafya, siyaset, din gibi bir ülkenin dinamiklerini derinden etkileyen faktörlerin çeşitliliği, bunların her coğrafyada farklı varlıklar göstermesi, sözü edilen ortak tanımı ve böylece disipline dair standart bir ilkeler bütünlüğü oluşturma girişimini imkânsız hâle getirmektedir.

Ortaya çıktığı günden bugüne farklı ülkelerden birçok edebiyat insanının fikirlerini beyan ettiği ve üzerine araştırmalar yaptığı Karşıllaştırmalı Edebiyat sahası, öne sürülen yaklaşımların farklılı̆ğın sebep olduğu kavramsal bir zenginlik sunmaktadır. Kavrama yönelik sınırlama meselesine, bir başka deyişle kavramın işaret ettiği anlamın nerede başlayıp nerede bittiği sorusuna dair cevap arama yolunda ifade edilen bakış açıları, bugün gelinen ve karmaşı bir görüntü sunan durumu tanımlayan unsurlar olmaktadır. Bu kavramsal çeşitlilik de dikkate alınarak geliştirilecek bu yazıda, tarihsel süreç çizgisinde ön plana çıkan belli başlı yaklaşımlardan bahsedilerek, Karşılaştırmalı Edebiyat terimini çevreleyen başka terimlere, ona alternatif olarak meydana getirilen başka isimlendirmelere yer verilecek ve aslında tüm bu unsurların, dünya edebiyatı fikrinin tamamlayıcı parçaları olduğu gösterilecektir.

Bu makale, olabildiğince farklı kültürel coğrafyalarda kendini gösteren fikirleri bir araya getirmek sureti ile Karşılaştırmalı Edebiyat kavramına bütüncül 
bir çerçevede bakmayı sağlamayı amaçlamaktadır. Bu bağlamda, "Welttiteratur ve Sonrası" ismi verilen ilk kısımda, Goethe ile edebî terminolojiye giren Weltliteratur kavramından hareketle, Karşılaştırmalı Edebiyat disiplinine yönelik kavramsal bir inceleme sunularak tarihsel bir görünge ortaya konulacaktır. Edebiyat insanlarının yaklaşımlarından hareketle sunulacak kavramsal yaklaşımın ardından, "Akademik Geçmiş ve Bugün" adlı ikinci kısınmda ise disiplinin akademik platformda ilk olarak nasıl ortaya çıktığı ve bugün dünyanın farklı üniversitelerinde hangi isimlerle kendine yer bulduğu gösterilecektir. Bu yapıllırken, olabildiğince farklı coğrafyalarda yer alan üniversitelerdeki durumdan kısaca bahsedilecek ve böylelikle daha kapsamlı bir resim sunulmaya çalışılacaktır. Bu bağlamda, on dokuzuncu yüzyılda, dünya edebiyatı kavramı ile temeli atılan ve sonrasında yöntemsel bir zemin kazanarak disiplin hâlini alan Karşılaştırmalı Edebiyat kavramının gelişiminde dikkati çeken değişim ve dönüşümler gözlemlenerek, bu kavram çerçevesinde, bugün gelinen durum en somut ve kapsamlı şekliyle irdelenecektir.

\section{Weltliteratur ve sonrası}

Weltliteratur yani dünya edebiyatı kavramı, on dokuzuncu yüzyılda ortaya atıldığı zaman, milletlerin birbirini tanımasına köprü olacak şekilde, millî olanın ötesine geçme fikri ile kendini göstermiştir. Karşılaştırmalı Edebiyat fikrine temel olarak Goethe'nin öne sürdüğü ve kendisi tarafından net bir tanıma kavuşturulmasa da genel olarak "milletlerin birbirlerini karşlıklı olarak düzeltmelerine ve ulusal sınırlar içerisinde kaldıklarında göremedikleri yönlerini daha iyi görmelerine olanak sağlayacak" (D’haen-Dominguez vd. 2013: 11) elverişli bir durum şeklinde tanımlanabilecek bu kavram, Alman yazarın yaşadığ 1 dönemi izleyen yıllardan günümüze gelene dek farklı bakış açılarından hareketle yorumlanagelmiştir. Goethe'nin ölümünden hemen sonra, örneğin, Alman edebiyat bilimcilerince, bu kavram, edebiyat tarihçiliğinin yükselişi ile paralel olarak, "dünya klasiklerinin bütünü” şeklinde bir tanıma sokulmuştur (D’haen-Dominguez vd. 2013: 10). O dönem için dünya klasikleri ile kastedilen coğrafyanın, bir elin parmaklarını geçmeyen Avrupa ülkelerinin oluşturduğu dar bir alandan ibaret olduğunu bu noktada hatırlatmak gerekir. Nitekim Cemil Meriç, dünya edebiyatı fikrinin gelişmeye başladığı 1830'lu yıllarda söz sahibi olan dört edebiyat coğrafyasından şu şekilde bahseder: Almanya, İngiltere, Fransa ve İtalya (2018: 38). 
Goethe'nin yazışmalarında da Almanya, Fransa ve İngiltere başta olmak üzere, bu dört ülkeden sıkça bahsedilmektedir (D’haen-Dominguez vd. 2013: 10-15). $\mathrm{Bu}$ dar çerçevesinden ötürü, Weltliteratur, önceleri, “Avrupa edebiyatı" kavramı ile eş tutulur hâle gelmiştir ki bu durum sonraları dünya edebiyatı yaklaşımının Avrupa-merkezci olması şeklinde eleştirilmesinin yolunu açmıştır. Bu yönde eleştiri getirenlerden René Etiemble en çarpıcı örnek olarak sayılabilir ki 1968 tarihli bir makalesinde Weltliteratur kavramına karşılık gelen tanımların yeniden gözden geçirilmesi üzerine ifade ettiği düşünceleri, o zamana kadar süregelen dünya edebiyatı tanımlarına en radikal yaklaşım olarak kabul edilebilir. Etiemble, Avrupa dışında kalan coğrafyaların dünya edebiyatına katkısının gerçek anlamı ile irdelenmediğini ve bu yüzden dünya edebiyatının merkezine hâlen Avrupa coğrafyasının yerleştirildiğini dile getirmiştir (D’haen-Dominguez vd. 2013: 93-95). Fransız edebiyat eleştirmeni, öte yandan, Avrupa dışında kalan coğrafyalarda da "dünya edebiyatı" klasikleri söz konusu olduğunda Avrupa edebiyatlarının ağır bastığını, söz konusu coğrafyaların da "dünya" resimlerinin bu anlamda eksik olduğunu ifade etmiştir (D’haen-Dominguez vd. 2013: 97-99). Yirminci yüzyılın öne çıkan edebiyat figürlerinden olan Etiemble, Weltliteratur kavramını, "sözlü olsun ya da yazılı olsun, yaşayan ya da antik tüm edebiyatları dil, siyaset ya da din ayrımı yapılmaksızın" kapsayacak şekilde geniş bir tanıma oturtmaya çalışmışırır (D’haen-Dominguez vd. 2013: 96).

Ortaya çıktığı dönemde, barındırdığı "dünya" sözcüğü ile çok dar bir coğrafyaya işaret eden Weltliteratur kavramı, değişen dünya şartları ve yöneltilen eleştiriler aracılığıyla, zamanla daha geniş bir coğrafyayı içine alacak biçimde bir tarihsel sürece girmiştir. Bu şekilde bir gelişim seyri devam ederken, bu kavrama alternatif ya da bu kavramla aynı zemini paylaşan başka kavramlar da kendini göstermiştir. Bu noktada, Karşılaştırmalı Edebiyat disiplini ile bağdaştırılan erken dönem kavramlarından biri "genel edebiyat tarihi" (Fransızcada "histoire littéraire générale", Almancada "Literaturgeschichte") kavramıdır. Edebiyatı uluslararası nitelikte tarihsel bir zemine oturtma ve böylece onu tarihsel gelişim çizgisinden hareketle inceleme fikrinden doğan "genel edebiyat tarihi”, böylece edebiyatı etkileyen iç ve dış faktörler üzerine yoğunlaşan bir akademik çalışma eğilimi gerçekleştirilmesine sebep olmuştur. Bu kavramla özdeşleşen isimlerden biri olan Fransız Paul Van Tieghem'in "histoire littéraire internationale" (ulus- 
lararası edebiyat tarihi) ismi ile tanımladığı genel edebiyat tarihi, Fransa'da, gelişim gösterdiği ilk dönemlerde, "edebî eserlerin ortak bir kökenden ve yabanc1 faktörlerden hareketle nasıl bir karakter kazandığını" inceleyen bir araştırma kolu olarak tanımlanmıştır (Brunel 2009: 70). Bu bağlamda, etki-kaynak merkezli çalışmalara ağırlık verilerek geliştirilen "fikirler tarihi" (Fransızcada histoire des idées) kavramı, akademik terminolojide, edebiyat tarihi yaklaşımı ile bağlantılı olarak kendine yer edinmiştir. Buna göre, bir fikir olarak edebî bir akımın, edebî bir türün nasıl bir tarihsel gelişim izlediğine dair araştırmalar yapılmış, böylelikle dünya edebiyatına şekil verdiği düşünülen fikirlerin kaynağına gidilmeye çalış1larak, diğer yandan onun etki alanının olabildiğince kapsayıcı şekilde göz önüne serilmesi amaçlanmıştır. Fikirler tarihi, "dil, ırk, yurt, iklim gibi faktörlerin oynadığ rolün ötesinde, milletlerin fikirlerden etkilenmesine ya da bu fikirlerin ortaya çıkmasına sebep olan yalnızca estetik etkenler" (Brunel 2009: 97) göz önünde tutularak gerçekleştirilen bir yaklaşımı işaret etmektedir. Bu yönüyle de saf bir tarihsel inceleme olmaktan çıkarak, edebiyat sahasının bir parçası hâline gelmiştir. Bu çerçevede gerçekleştirilen çalışmalar "karşılaştırmalı estetik" (Fransızcada esthétiques comparées) adı ile de anılmıştır (Brunel 2009: 97). O hâlde, edebiyat tarihi üst bir çalışma alanı olarak düşünülecek olursa, fikirler tarihi bir yaklaşım, karşılaştırmalı estetik ise edebiyat tarihi altında irdelenebilecek alt bir çalışma alanı olarak karşımıza çıkmaktadır. Alman edebiyat insanlarınca da benimsenen "edebiyat tarihi" yaklaşımı, bilimsel araştırma anlamında, Karşılaştırmalı Edebiyatın evrim sürecinde ilk önemli aşama olmuştur. Almanya'da Moritz Carrière, Karşılaştırmalı Edebiyatı "genel medeniyet tarihinin içerisine dâhil etmek" gayesi ile bir dizi konferans düzenlemiştir (Brunel 2009: 22).

Genel edebiyat tarihi çalışmalarında araştırma eğilimleri, eşzamanlılık (Fransızcada synchronie) ve artzamanlılık (Fransızcada diachronie) olarak iki ana yaklaşım üzerinden kendini gerçekleştirmiştir. Bunun yanında, bu tür çalışmaların devamlı olarak belli coğrafyaları referans olarak alması ve diğerlerini dışarıda bırakması, edebiyat tarihinin en önemli handikaplarından biri olmuştur. Bu bağlamda, bir edebî türün tarihsel gelişimi üzerine kaleme alınmış çalışma ya da çalışmalarda, ele alınan edebî tür ile ilişkilendirilebilecek başka edebî ve coğrafî varlıkların ve unsurların Avrupa dışında kaldıkları için tarihsel süreç içerisine dâhil edilmemesi, "genel” ibaresinin eksik kaldığı fikrini vermiştir. Bunun ile ilgi- 
li olarak, örneğin, Etiemble, bir edebî tür olarak tiyatronun tarihsel süreci ele alındığında, bu tür için önemli bir yeri olan Japon tiyatrosundan Avrupa'da yayınlanmış edebiyat tarihi eserlerinde bahsedilmemiş olması durumunu, adı geçen edebî türün "genel" resminin verilememiş olmasına eş tutmuştur (Damrosch 2014: 93).

Edebiyat tarihi ile ilişkilendirilen bir başka sorun ise périodisation yani dönemlere ayırma sorunudur. Ortak bir edebiyat tarihini dönemlere ayırırken, genelgeçer bir sınıflandırmanın ne denli imkânsız olduğu sorunu belirginlik kazanmıştır. Aynı tarihsel ve kültürel çizgiyi izlemeyen milletlerin ortak bir tarihini yazarken, "klasik çağ", "Rönesans" ya da "romantik çağ" gibi isimlendirmelerin, batı Avrupa ülkeleri için geçerlilik taşıması, bunlar dışında kalan ülke edebiyatları için aynı şekilde bir karşılığının olmayışı, edebiyat tarihinin yüzleşmek zorunda kaldığı olgulardan olmuştur. Öyle ki Avrupa'nın geçirdiği tarihsel süreci merkeze alarak, bunu dünya ölçeğine uyarlamaya çalışma eğilimi, Avro-kronoloji diye çevrilebilecek Eurochronology kavramı ile de eleştirilmiştir ve eleştirilmektedir (Küpper 2013: 40). Hâl böyle iken, dönemlere ayırma zorluğu ile de beraber, "genel" bir dünya edebiyatı tarihi projesinin ne derece gerçekleştirilebileceği, tartışmaların odağı hâline gelmiştir.

Edebiyata ve edebiyatlara tarihsel açıdan yaklaşmak ve bu sayede bir dünya edebiyatı resmi ortaya koymak, daha sonra "Fransız Ekolü" olarak da anılacak bir Karşılaştırmalı Edebiyat vizyonunun şekillenmesine yol açmıştır. Ancak, edebiyatı yalnızca bir tarih dalına indirgemek, sonraları eleştirilerin odağı olmuş ve dünya edebiyatı incelenirken, işin içerisine tarihten başka unsurların da dâhil olduğunu savunan görüşler kendini göstermiştir. Bunlar içerisinde, Çek asıllı René Wellek, Fransız yaklaşımını çok fazla pozitivist bulmuş (Pageaux 1994: 11) ve edebiyatın salt bir bilim dalından farklı şekilde ele alınması gerektiğini savunmuştur. Aynı şekilde, Fransız ekolünün yaklaşımına karşı çıkanlar için genel edebiyat ve Karşılaştırmalı Edebiyat şeklinde bir ayrım yapaydır (Brunel 2009: 100). Özellikle “Amerikan Ekolü” ismi ile özdeşleştirilen ve Karşılaştırmalı Edebiyat fikrinin sınırlarını, Fransız geleneksel yaklaşımının çok ötesine taşımak gayesi ile kendini meşrulaştıran bu eleştirel tutum, bu kez de sınırların nerede bittiği üzerine yapılacak tartışmaların odağı olmuştur. Bu aşamada, Fransız Jean-Marie Carré, Amerika'da öğretilen genel edebiyatın, Karşılaştırmalı Edebiyat olmadığını, burada öğretilen hümanizm, klasisizm, romantizm, realizm, sembolizm gibi büyük 
ölçekli etkiler yaratmış ve eşzamanlılık prensibine göre de ele alınabilecek fikir paralelliklerinin, zaman ve coğrafya açısından çok geniş bir yayılma göstermiş olmasından dolayı soyut, keyfî ya da derinliği olmayan bir listeden ibaret kalma gibi riskli sonuçlar verebileceğini ifade etmiştir. Carré, Karşılaştırmalı Edebiyatın bu tip büyük ölçekli sentezlere zemin hazırlasa da bunlara tam anlamıyla imkân veremeyeceğini dile getirmiştir (Franco 2016: 57). Brunel, Pageaux, Chevrel gibi çağdaş Fransız edebiyat eleştirmenlerinin Karşılaştırmalı Edebiyat disiplini üzerine yayınladıkları kitaplarda da sınırlama olgusunun, Karşılaştırmalı Edebiyat çalışmalarında olmazsa olmaz bir konu olarak yer bulduğu göze çarpmaktadır.

“Amerikan Ekolü” ile de özdeşleştirilen ve Karşılaştırmalı Edebiyat terminolojisinde kendine yer edinen bir başka kavram, genel edebiyat (İngilizcede general literature) kavramıdır. Ortodoks bir Karşılaştırmalı Edebiyatın karşısında genel edebiyatın gittikçe etki alanını daha fazla genişlettiği ve söz konusu durumun 1968'den beri Fransa'da da kendini iyiden iyi hissettirdiği görülebilmektedir (Brunel 2009: 28). Bununla birlikte, Fransa'da, genel edebiyat ve Karşılaştırmalı Edebiyat kavramlarını iki ayrı kavram olarak ele alan yaklaşım bugün de hâkimdir. Bu iki kavram arasında ne tür bir fark olduğu üzerine fikir birliği yoksa da 1921'de yayımlanan bir makalesinde Tieghem, genel edebiyatı "ulusal sınırları aşan edebî akımlar ve formlar üzerine çalışma", Karşılaştırmalı Edebiyatı ise "iki veya daha fazla edebiyatı birleştiren ilişkiler üzerine çalışma” şeklinde yorumlamıştır (Brunel 2009: 100). Daha sonra, bir başka Fransız, Jean-Marie Carré ise, Tieghem'in genel edebiyat tarihi yaklaşımından hareketle, "edebî akımları, edebiyat eserleri arasındaki bağları, özellikle diğer sanatlar, siyasî etkenler, toplumların değişimi ve dönüşümü noktalarından hareketle estetik yönelimleri” üzerinden ele alan bir araştırma sahası (Franco 2016: 58) şeklinde irdelediği "genel edebiyat" (littérature générale) kavramına daha spesifik bir tanım getirmiştir.

Fransız edebiyat insanları, genel edebiyat kavramının Amerikalı edebiyat insanlarınca, yer yer Karşılaştırmalı Edebiyatın eş anlamlısı, yer yer evrensel edebiyatla karışan, yer yer edebiyat kuramına kayan, bazen de hiç var olmayan bir kavram olarak ele alınmasını ironik bir şekilde dile getirmişlerdir (Brunel 2009: 100). Kavramın "muğlak" bir çağrışımı olduğundan ötürü tek başına kullanılmadığı, bundan dolayı da Fransa başta olmak üzere başka ülkelerde Karşılaştırmalı Edebiyat kavramı eşliğinde kullanıldığı görülmektedir (Chevrel 2016: 18). 
Nitekim bugün hâlen Fransa'da Karşılaştırmalı Edebiyat çalışmalarında, uzmanı olunan belli başlı alanların (spécialités) olması beklenmektedir. Aynı zamanda, eserlere orijinal dilinden erişim yaklaşımının ağırlıklı olarak kabul gördüğü Fransa'da, araştırma yapılacak aslî kaynakların ya da edebiyatların diline hâkim olunması gerektiği kuralı ile de araştırmacılara bir sınır çizme eğilimi söz konusudur. Yirminci yüzyıldan itibaren, "Yabancı Diller, Edebiyatlar, Medeniyetler" kavramı, millî edebiyat dışında kalan edebiyatları "genel" anlamda inceleyen bir çalışma sahasını tanımlamaktadır. Bu ismi taşıyan akademik kürsüler Fransa'da bugün hâlen mevcuttur.

Genel edebiyatın yanında, Fransa'da bir başka terim daha Karşılaştırmalı Edebiyat fikri ile beraber tartışılmıştır: edebiyat felsefesi (Fransızcada philosophie de la littérature). Edebiyatı bir epistemoloji sahası olarak ele alan bu kavrama göre, ele alınan yazarlar, dönemler, diller ne denli çeşitli olursa, edebiyat felsefesi fikrine o kadar yakınlaşılmış olur. "Edebiyat ve gerçeklik", "şiir ve müzik", "biyografi ve yaratım" gibi konular bu kapsamda, edebiyat felsefesi çerçevesinde düşünülebilir. Burada asıl önemli olan, bir bütün olarak edebiyatın temel verileri üzerine okurun düşünmesini ve değerlendirmesini harekete geçirmektir (Brunel 2009: 107).

Karşılaştırmalı Edebiyat ile bağlantılı olan bir başka olgu, dil ve çeviri olgusudur. Goethe'nin öne sürdüğü ve "çeviri temelli çokdillilik" (translated multilingualism) yaklaşımı, yirminci yüzyıla gelindiğinde, "yeni dünya edebiyatı" (new world literature) olarak adlandırılan ve kendisini ayırt eden özeliklerini "çevrilemez dil çeşitliliği" (non-translatable mixtilingualism) ya da "evrenselanlaşılabilir dil çeşitliliăgi" (mixtilingualism to be universally understood) olgularından alan bir yaklaşıma isim olmuştur. Bu yüzyılda, birden çok yerel dile sahip olan ve "ulusal-yerli çokkültürlülük" (national Indigenous multiculturalism) kavramı ile anılan Brezilya örneğinde olduğu gibi, ortodoks ulusal tek dil yaklaşımına alternatif olarak, birçok dillilik eğiliminin ortaya çıktığı gözlemlenmektedir (Sturm-Trigonakis 2013: 72). Diller ve ulus kavramı arasındaki dengeler çok dillilik, dilsel çeşitlilik, dilsel görünürlük, dilsel anlaşılabilirlik, dil ve kimlik gibi faktörler aracılı̆̆ ile bir değişim içerisine girmiş ve bu iki kavram arasındaki ilişkinin tanımının değişmesine yol açmıştır.

"Yeni Karşılaştırmalı Edebiyat" (İngilizcede New Comparative Literature) olarak da nitelendiren ve "dünya filolojisi”, "Welt-hümanizm”, "dilbilimsel 
kozmopolitizm" fikirleri ile temellendirilen, Leo Spitzer ve Erich Auerbach öncülüğünde gelişmeye başlayan ve sonrasında "yakın okuma" (İngilizcede close reading) kavramı ile özdeşleştirilen ve İstanbul Ekolü olarak da isimlendirilebilecek girişim, yirminci yüzyılın başlarında, oldukça geri planda, varlığını sürdürmeye çalışan Karşılaştırmalı Edebiyat sahasının, aynı yüzyılın ortalarına gelindiğinde, akademik anlamda yeni bir açılım yakalamasına sebep olacaktır (Apter 2006: 50). Metinleri ve içerdikleri sözcükleri birer "dünya" olarak ele alan yakın okuma, metni, teolojik bir perspektiften hareketle, adeta kutsal bir yaratım olarak görmektedir (Apter 2006: 64). "Mimesis" kavramı ile açılanan bu durum, dünya edebiyatı kavramını, ulus birlikteliğinden öte metin birlikteliği ilkesine göre yeniden değerlendirmiştir. Dil ve ulusu birbirinden ayrı ele alan Auerbach, "dilin bilimi için bir ev var ise o ev ulus değil dünyadır (die Erde)" diyerek, dünya dil bilimi (World philology) terimi aracıllğ 1 ile ulus olgusunun ötesinde bir dil evrenselliğini işaret etmektedir (Küpper 2013: 43). Auerbach'ın "mimesis" kavramı üzerinden öne sürdüğü ve teolojik bir bakış açısıyla ele aldığı, dolayısıyla Tanrı imajı ile özdeşleştirdiği mükemmel birliktelik ancak yeryüzünü oluşturan çeşitliliğin bir araya gelmesi ile mümkün olabilir (Küpper 2013: 54).

Dili ulus kavramından bağımsız ele alan dilbilimsel hümanizm anlayışı ve ona şekil veren mülteci kimliği, Auerbach'ın, yirminci yüzyılın bir başka önemli aktörü, Filistinli düşünce insanı Edward Said ile ulusötesi hümanizm (İngilizcede transnational humanism) kavramı etrafinda buluşmalarını sağlamıştır. Debjani Ganguly’ye göre, yirminci yüzyılda, insan varlı̆̆ını olumsuz yönde etkileyen "milliyetçilik" (nationalism), "dinsel etnik-merkezcilik" (religious etnocentrism) ve "dışlayıcılık" (exclusivism) gibi eğilimler karşısında, Said'in metinlere yaklaşımda benimsediği, dillerarası (translational), ulusötesi (transnational), zamanötesi (transtemporal) olan ve aynı zamanda, küresel ( global) olanı tanımlayan baskın siyasî ve ekonomik kodlar ile uyuşmazlık içerisinde bulunan bakış açısı ile birlikte, "seküler eleştiri”" (secular criticism) Karşılaştırmalı Edebiyat terminolojisinde meşru bir yer edinmiştir (Behdad-Thomas 2011: 440). Öyle ki Emily Apter gibi edebiyat insanlarınca Avrupa-merkezci olmakla eleştirilen Auerbach'ın hümanizm anlayışı, Said'de daha kapsayıcı bir boyuta ulaşacaktır. Seküler eleştiriye göre, basmakalıp, çağdışı, baskın, teksesli, dokunulmaz yorumlama ve yaklaşımların yerini, gerçek zamanlı şartlar altında yenilenebilen çağdaş yorumlama 
ve yaklaşımlar alırsa, çoksesli bir okumanın gerçekleşmesi olanaklı olur. Bu bağlamda, Said ile beraber anılan bir başka terim olan "çoksesli okuma" (contrapuntal reading), eserleri incelerken, sürekli kendini yenileyen nitelikte eleştirel bir yaklaşımı esas alarak, sözcüklere, metinlere yüklenen anlamların, bunların yorumlanma şeklinin eleştirel bakış açısının niteliğini belirlediğini işaret eder (Behdad-Thomas 2011: 440). Spitzer, Auerbach ve sonrasında Said'in öne sürdügü fikirler ve tespitler ile edebiyat, dilbilim ve hümanizm kavramları arasındaki ilişki yeni bir boyut kazanarak, dar bir alana sıkışmış Karşılaştırmalı Edebiyat sahasında ihtiyaç duyulan yeni açılımların meydana gelmesine sebep olmuştur. Bu üç ismin "Doğu" ile olan kökensel ya da deneyimsel münasebetleri ve mülteci kimlikleri, bahsi geçen açılımların gerçekleşmesi sürecinde başat faktörler olmuşlardır. Nitekim "Batı” olarak adlandırılabilecek ve Avrupa'nın bir kısmını içerisine alan dar coğrafyanın sınırları dışına, savaş koşulları yüzünden çıkmak zorunda kalan Spitzer ve Auerbach gibi entelektüel aktörler; "Doğu" kökenli bir entelektüel olarak, yine savaş koşulları yüzünden, bu kez "Batı" olarak adland1rılabilecek ve Amerika Birleşik Devletleri sınırlarını işaret eden coğrafyaya iltica etmek durumunda kalan Said, Karşılaştırmalı Edebiyatın dinamikleri arasında sayılabilecek dil, ulus, birey, aidiyet, farklılık, birliktelik kavramlarını "dışarıdan" görebilme ve bunlara daha eleştirel yaklaşabilme olanağına erişmişlerdir. Böylelikle, yirminci yüzyılın önemli sorunlarından ya da fenomenlerinden biri olarak ifade edilebilecek iltica ve mültecilik meselesi, edebiyatta hümanizm kavramının yeniden şekillenmesine ve çok büyük çaplı olmasa da onun daha kapsayıcı, daha hümanist bir zemine kavuşmasına neden olmuştur.

Yukarıda bahsedilen, metin merkezli "yakın okuma” yaklaşımına karşılık olarak, yirminci yüzyılın sonlarına gelindiğinde, Franco Moretti tarafından öne sürülen, mesafeli okuma (distant reading) adı ile anılan ve tema, motif, şema gibi metinötesi unsurları, metnin önüne geçiren bir yaklaşım ortaya çıkar. Moretti'ye göre, bu yaklaşım sayesinde metinden çok daha büyük ya da daha küçük yap1lara erişilebilir. Zira Moretti için, bu tür bir okuma, bir "bilgi edinme" koşuluna denk gelmektedir. Burada asıl amaç bilgi edinme olduğundan, bu tarz bir okuma yüzünden, metnin kendisi, metinötesi unsurların arkasında kalmaya başlayıp, "kaybolmaya yüz tutuyorsa, bu da büyük bir kayıp sayılmaz" (Apter 2006: 43). Dünya edebiyatı kavramını pasif bir olgudan (object) ziyade, bir mesele (problem) 
olarak gören Moretti için, bu noktada, dünya edebiyatı kavramına yaklaşımda ihtiyaç duyulan şey, metin okumanın ötesine geçilip, bir yöntem benimsenmesidir (Prendergast 2004: 149). Moretti'nin ileri sürdüğü bu görüş, bazı eleştirmenlerce, metinleri, metindışı unsurları önceleyerek değerlendiren geleneksel Karşılaştırmalı Edebiyata dönüş olarak yorumlanmıştır. Bu tutum, söz konusu bağlamda, Margaret Cohen tarafından, "yakın okuma” yaklaşımından kurtulmaya çalışma refleksi ile ikinci elden malzemelere, umarsızca, sırtını dayayan ve entelektüel enerjiyi, sentez idealinin gerçekleşebilmesi uğruna ziyan eden bir çeşit "edebiyat eleştirisi takıntısı" olarak değerlendirilmiştir (Apter 2006: 43). Nitekim burada anılan "edebiyat eleştirisi" ifadesi, "Eski Karşılaştırmalı Edebiyat" olarak da anılan ve Fransız Ekolü ile bağdaştırılan, metinleri tarih ve coğrafya gibi metindışı dinamikler üzerinden değerlendiren ve bunu yaparken pozitivist kuramlara sık1 sıkıya bağlı kalan tutumu işaret etmektedir.

Moretti'nin yaklaşımına öncül olarak yirminci yüzyılın sonlarında ortaya çıkan ve sosyolojik açıdan edebiyatı tanımlama girişimi olarak şekillenen, Pascale Casanova'nın öne sürdüğü, edebiyatı bir sistem olarak ele alan ve bu sistemi tarihsel ve coğrafî olmak kaydı ile değerlendiren bir başka yaklaşım kendini gösterir (D'haen 2012: 102). Bu yaklaşım, dil ve ulusu ayrılmaz parçalar olarak görür ve edebiyatı ulus olgusu üzerinden, bir sistemin parçası olarak değerlendirir. Casanova'nın bu yaklaşımı, metindışı unsurları referans olarak kabul eder ve uluslararası edebiyat kavramını, merkez (centre) ve çevre (périphérie) terimleri ile sistemleştirmeye çalışır. Bu yönüyle, edebiyatları ve dilleri, çizgileri çok net olmayan esaslara göre sınıflandırmaya çalışarak genelleyen ve aynı zamanda Avrupa, ya da roman türünde ileri sürdüğü üzere Fransa, merkez olmak üzere diğer edebiyatlara indirgemeci bir tutumla yaklaşan Casanova ve onun "dünya edebiyatlar cumhuriyeti” (Fransizcada La République mondiale des lettres) fikri, Marksist kuramın ve Itamar Even-Zohar'ın çoğul dizge kuramının da izlerini taşıyarak, "merkez" ve "çevre" edebiyatları, birbirleri ile çatışma içerisinde bulunan, güç ve sınıf kavramları ile tanımlanabilecek dinamik bir sistemin parçaları olarak kabul etmiştir. Casanova, edebiyatları, edebî olmalarının ötesinde, tarihsel ve coğrafî koşullardan hareketle, geniş bir çerçevede ele alarak, yakın okuma yaklaşımı ile arasına böylelikle bir mesafe koymuştur. Bu noktada, Christopher Prendergast, Casanova'nın, yazılı ve konvansiyonel edebiyatı karşılayan, Fransızca littérature 
ve ulusal edebiyat kavramları ile genelleyici bir tavır benimseyerek, sözlü edebiyat ya da azınlık edebiyatları gibi unsurları göz ardı ettĭgini ve Casanova'nın temellendirmeye çalıştı̆ı uluslararası edebiyat sisteminin, esas itibarı ile etnikmerkezci (ethnocentric) bir kategorileştirme girişimi olduğunu dile getirmiştir (Prendergast 2004: 22).

Yukarıda adı geçen ve Fransa ve Amerika Birleşik Devletleri ile özdeşleştirilen iki ekol ekseninde fikir ayrılıkları süregelirken, dünya edebiyatı fikri, bu iki ülkenin dışında yer alan kültür coğrafyalarında yaşayan edebiyat insanlarının da ilgisini çekmiş ve küreselleşme yörüngesine yavaş yavaş giren dünya şartlarında, edebiyatın da küresel bir rolünün olup olmadığı daha geniş çaplı biçimde tartışılmıştır ${ }^{1}$. Edebiyatın olabildiğince kucaklayıcı ve kapsayıcı olması gerektiği ve ancak bu şekilde bir "edebiyatlar cumhuriyeti” idealine yaklaşılabileceği düşüncesi ile beraber, yirminci yüzyıla gelindiğinde, bu kapsayıcılık kendini iyiden iyiye belli etmeye başlamıştır. Genel ya da uluslararası edebiyat tarihi kavramlarının dünya edebiyatı kavramını karşılamada yeterli olamadığı görüşü ile birlikte, Karşılaştırmalı Edebiyat ile bağlantılı kavramların çeşitliliği de artmaya devam etmiştir. Bu bağlamda, 1964 tarihinde "Weltliteratur Kavramını Yeniden Gözden Geçirmeli Mi?" (Fransızcada Faut-il réviser la notion de Weltliteratur?) başl1ğını taşıyan bir yazı kaleme alan Fransız René Etiemble, Weltliteratur teriminin birebir karşıllğı olan dünya edebiyatı kavramı yerine, daha kapsayıcı ve işlevsel olduğunu düşündüğü evrensel edebiyat (Fransızcada littérature universelle) kavramını ön plana çıkarmıştır. Öyle ki Fransızcada, uluslararası edebiyat ve yabancı edebiyatlar gibi adlandırmalar, dünya edebiyatı kavramına göre daha yaygın bir kullanıma sahiptir. Fransa' daki bu tutumdan farklı olarak, Anglosakson coğrafyada, özellikle de Amerika Birleşik Devletleri ölçeğinde, "World Literature" kavra$\mathrm{m} 1$ bugün hâlen güncelliğini korumaktadır. Bunda şüphesiz, eserlerini bu kavram etrafında şekillendiren David Damrosch'un yadırganmayacak bir rolü vardır.

Yirminci yüzyıl, Karşılaştırmalı Edebiyat disiplininin Türkiye'deki varlığ açısından da önemlidir. Yabancı dillerden çevirinin ivme kazandığ bir dönemde, Paul Van Tieghem'in 1931 tarihinde yayınlanan "La Littérature comparée" adlı eseri 1940’ta Türkçeye, Yusuf Şerif Kılıçel tarafından, orijinal isminin bire-

1 Bkz. D'haen, Theo \& Dominguez, Cesar \& Thomsen, Mads Rosendahl (2013), World Literature: A Reader, Oxon: Routledge ; Damrosch, David (2014), World Literature in Theory, ed., West Sussex: Wiley Blackwell. 
bir karşı1lığı olan "Mukayeseli Edebiyat" adı ile çevrilerek yayınlanmıştır. Yine aynı yüzyılda, 1980 tarihli bir yazısında, "dünya edebiyatı" kavramını tartışırken, Cemil Meriç, dünya edebiyatı tabiri ile beraber evren sözcüğüne karşılık gelen "cihan" kelimesinden türetilen "cihanşümul edebiyat" kavramını da dile getirmiştir (Meriç 2018: 25). Bu kavramlar, Karşılaştırmalı Edebiyatın Türkçedeki ilk karşılıkları olarak yerini alırken, Türkiye'de bu disipline dair ilk bölümün kurulduğu 1996 yılına gelindiğinde, Türk dilinde gerçekleşen değişimlerin sonucunda, açılan bölümün adı "Mukayeseli Edebiyat" kavramına karşılık gelen "Karşılaştırmalı Edebiyat" olacaktır. Disipline dair Türk dilinde kaleme alınmış az sayıdaki eserden en bilineni, Gürsel Aytaç'ın 2001 tarihli kitabıdır ki bu eser için belirlenen isim, yazarının de dile getirdiği üzere, Almanca dilindeki karşıllı̆ının etkisiyle, Karşılaştırmalı Edebiyat Bilimi olmuştur.

Yirmi birinci yüzyıla gelindiğinde, Karşılaştırmalı Edebiyat, dünya edebiyatı kavramının ötesine geçmesi gereken, öte yandan, Damrosch'un küresel tüketimcilik (global consumerism) ve pazar realizmi (market realism) ile açıkladığı küresel edebiyat (global literature) kavramına indirgenmemesi lazım gelen bir kavram olarak karşımıza çıkar (Küpper 2013: 18). Bu çerçevede, Gayatri Chakravorty Spivak, disiplinin "gezegensellik" (planetarity) prensibini özümseyen bir niteliğe kavuşamaz ise var olma nedeninin kalmayacağını ileri sürerek, dünya edebiyatı ya da küresel edebiyat gibi dar anlamlara sahip olduğunu düşündüğü kavramlar yerine, olabildiğince kapsayıcı bir anlam genişliğini bünyesinde barındırdığını kabul ettiği, gezegende geçici olarak bulunduğumuzun altını çizen "diğerlik" (alterity) kavramı ile bağdaştırdığı, bir düzeni tanımlayan bu terimi (Apter 2013: 189), Karşılaştırmalı Edebiyatın kurtuluş anahtarı olarak sunmuştur. Adı geçen "diğerlik", emperyalist bakış açısından ve "medenî/canavar" ikiliğinden sıyrılmış, bir merkezi ya da çıkış noktası olmayan radikal (underived) bir sisteme denk gelmektedir (Moore-Rivera 2011: 282). Spivak'ın radikal diğerlik vurgusu, yirmi birinci yüzyılın ön plana çıkan edebiyat insanlarından olan Apter'da, Kenneth Reinhard'dan esinlenilen "komşuluk" (neighborhood) kavramından hareketle, "ev sahibi/misafir" ikiliğinin ortadan kalktığı, diğer olanı tekdilliliğe, bir başka deyişle tek yönlü yorumlamaya indirgemeyen, çevrilemez (untranslatable) olanın muhafaza edildiği bir karşılaştırma fikri olarak kendini gösterir (Apter 2006: 247). Hâl böyle iken, içerisinde bulunduğumuz yüzyılda, Karşılaştırmalı Edebiyat, et- 
nik-merkezcilikten, tekdillilik ya da tekkültürlülük gibi indirgeyici eğilimlerden kurtulmuş, bir kaynağı ya da merkezi olmayan bir edebiyat anlayışını gerçekleştirmek adına var olan bir disiplin olarak dizayn edilmeye çalışılmaktadır.

Kavramsal olarak edebiyat tarihi, edebiyat felsefesi, genel edebiyat, dünya edebiyatı, yabancı edebiyat, evrensel edebiyat gibi farklı adların oluşturduğu bir bütünlüğü işaret eden Karşılaştırmalı Edebiyat, akademik çatı altında da birçok farklı adlandırma ile varlık göstermiştir, göstermektedir. Bundan ötürü, şimdiye kadar yer verilen ve edebiyat eleştirmenlerince ortaya atılan isimlendirmelerin yanı sıra, Weltliteratur kavramı ile başlayan Karşılaştırmalı Edebiyatın gelişim sürecinin en somut uzantısı sayllabilecek akademik kürsülerin nasıl isimler ile kurulduğunu da irdelemek gereği doğmaktadır. Böylece, bugün bir disiplin olarak nitelendirilen Karşılaştırmalı Edebiyatın ismine dair daha bütüncül bir değerlendirme yapabilmek mümkün olacaktır.

\section{Akademik görünürlük: Geçmiş ve bugün}

Weltliteratur fikri ile ortaya çıkan ve tartışılan, ardından Fransa'da, doğabilimci Cuvier tarafından Karşılaştırmalı Anatomi derslerinde kullanılan karşılaştırma yönteminin daha sonra edebiyata uyarlanması ile bilimsel bir beşerî disiplin olma yoluna giren Karşılaştırmalı Edebiyatın akademik sahadaki gelişimi, dünya edebiyatı fikrinin en önemli uzantısı olarak dikkate değerdir. Dünya edebiyatı yaklaşımına bilimsel bir zemin hazırlayan akademik kürsüler, birbirinden fark11 yönelimler benimseyerek, Karşılaştırmalı Edebiyat disiplininin, bir araştırma sahası olarak ele alınışında geniş bir seçenekler havuzunun meydana gelmesine yol açmışlardır. Söz konusu havuza dair olabildiğince geniş bir içerik sunmayı amaçlayan bu bölümde yer verilecek üniversitelerin çeşitlilik göstermesi adına, dünya üniversite sıralamasına girenlere öncelik verilmek kaydı ile tüm kitaları içine alacak bir coğrafya temsili gerçekleştirilmeye çalışılacaktır.

Çıkış noktası olarak kabul edilen Fransa'da, 1830 yılında, Sorbonne Üniversitesi bünyesinde Claude Fauriel tarafından "Yabancı Edebiyat" (Littérature étrangère) adı altında ilk olarak kurulan ve karşılaştırma yönteminden hareketle "farklı edebiyatlar arasında analoji yoluyla etki-kaynak araştırması" (Chevrel 2016: 7) yapmak gayesi ile kendini tanımlayan Karşılaştırmalı Edebiyat, bugün, bir akademik disiplin olarak farklı isimlere sahiptir. Öyle ki aynı ülke içerisinde 
bulunan üniversitelerde dahi farklı isimler kullanma yoluna gidilebilmiştir. Fransa dışında kurulan ilk Karşıllaştırmalı Edebiyat kürsüsü olan ve 1865 yılında Cenevre Üniversitesi bünyesinde açılan "Modern ve Karşılaştırmalı Edebiyat" (Littérature Moderne et Comparée) kürsüsü, bu disiplinin, ilk ortaya çıktığı dönemde, Fransız etkisiyle, modern olarak tanımlanan edebiyatları incelemesi sebebiyle bu ismi almıştır. Fransa'da kurulan ilk kürsünün isminin barındırdığ "yabancı" sözcüğü ise şüphesiz romantizm ile beraber yabancı olanın bir ilgi olgusu hâline gelmesi durumu ile açıklanabilir. Bununla beraber, yabancı ile "millî olmayan" vurgusu da göze çarpmaktadır. Nitekim bu döneme dek Fransa'da, edebiyat yalnızca Fransız Edebiyatı ve Antik Edebiyat (littératures de l'Antiquité classique) olarak iki referanstan ibaret görülmüştür (Chevrel 2016: 10).

Sorbonne Üniversitesinden sonra, Lyon Üniversitesi'nde ilk kez açılan "Yabanc1 Edebiyat" kürsüsünün kurucusu olan Edgar Quinet, "étranger" yani "yabancı" kelimesini kullanmak zorunda kaldığını dile getirmiştir. Quinet, verdiği derslerin asıl amacının yabancı edebiyatları öğretmek olduğunu, yine de bu kelimenin sanki tüm insanların sanatın ve zamanın ötesine geçmenin güzelliğini barındıran aynı şehri paylaşan yurttaşlar olmadığı izlenimi verebileceğini de ifade etmiştir (Marti Monteverde 2017: 299). Karşılaştırmalı edebiyatın Fransa'daki öncü isimlerinden olan Villemain, Ampère ve Chasles'dan farklı olarak Quinet, Fransız Edebiyatının diğer edebiyatlarla ilişkisine yoğunlaşmaktan ve böylece millî edebiyata merkezî bir statü vermekten öte, yabancı olan edebiyata ağırlık veren bir yaklaşım benimsemiştir (Marti Monteverde 2017: 299). Bu da aslında, ilkler arasında kabul edilen bu kürsüde, millî edebiyatın alanının, millî dışı edebiyatla bir anlamda ayrıştırıldığını ve buna göre bir edebiyat yaklaşımının şekillendiğini göstermektedir. Oysa Villemain, verdiği derslerin amacının, "Fransız ruhu" olarak tanımladığı millî olgunun yabancı edebiyatlardan aldığı ve onlara verdiklerini karşılaştırmalı bir tablo şeklinde göstermek olduğunu söylemiştir (Brunel 2009: 18). Villemain gibi Fransız akademisyenlerce, Karşılaştırmalı Edebiyatın amacı millî edebiyatı daha iyi tanımak biçiminde açıklanmıştır.

Yabancı edebiyat gibi, Karşılaştırmalı Edebiyat ile bağdaştırılabilecek bir başka çalışma sahası, aynı dili konuşan farklı ülkelerin oluşturduğu coğrafî bütünlük üzerinden geliştirilen çalışmalar olarak söylenebilir. Fransızcanın konuşulduğu coğrafyaların oluşturduğu bütünlüğe verilen ad olan ve on dokuzuncu yüz- 
yılın sonlarında ortaya atılan, yirminci yüzyılın ilk yarısında yaygınlık kazanan "Frankofoni" kavramı, millî sınırların ötesine geçebilmenin aynı dil içerisinde kalabilmeyle de mümkün olduğunu gösterecek bir araştırma sahasının meydana getirilmesine yol açmıştır. Ancak bu kavramın da tanımı noktasında soru işaretleri söz konusudur. Nitekim "Frankofon Edebiyat" ya da "Frankofon Edebiyatlar" olarak tanımlanan edebiyatların meydana getirdiği ve millî edebiyat dışında kalan bütünün "yabancı" nitelemesi ile tanımlanmasının mümkün olup olmadığı ve bu yüzden söz konusu sahanın "Fransız Edebiyatı" bünyesinde mi yoksa "Karşılaştırmalı Edebiyat" bünyesinde mi ele alınmasının daha yerinde olacağı tartışılmıştır (Chevrel 2016: 14). Yine bununla ilgili olarak, Apter, Frankofoni teriminin, Fransa Fransızcası merkez ve diğer ülke Fransızcaları çevre olarak düşünüldüğü takdirde, yeni-sömürgeci bir anlayışın uzantısı olacağını, ancak, söz konusu terimin, dünyada Fransızca ya da Fransızcaya benzeyen dillerin konuşulduğu bölgeler arasındaki iletişim ağını tanımladığı sürece kabul edilebilir bir kullanımının olacağını ifade etmiştir (Apter 2006: 87).

Frankofoni gibi bir başka dil birlikteliği sahası olan ve "Türkî” olarak adlandırılan, Fransızcada "Turcophone", İngilizcede "Turkic" sıfatı ile nitelenen coğrafyaların edebiyatları da millî olanın ötesine dil birlikteliği aracılığı ile geçebilmeye olanak sağlayan bir durumu işaret etmektedir. Bu bağlamda, Türkiye üniversitelerinde kurulan "Çağdaş Türk Lehçeleri ve Edebiyatları" bölümleri, bu tür bir olanağı akademik çatı altında mümkün hâle getirebilecek bir girişime örnek verilebilir ki Karşılaştırmalı Edebiyatın Türkiye ölçeğinde geliştirilmeye gereksinim duyan araştırma sahalarından biri olarak bu aşamada anılabilir. Söz konusu araştırma sahası, şüphesiz ki Türk lehçelerini konuşan kültür coğrafyaları arasındaki bağları daha canlı ve dinamik bir seviyeye taşıma gayesini benimsemektedir. Bu kapsamda kurulmuş olan ve Ankara Üniversitesi bünyesinde yer alan "Çağdaş Türk Lehçeleri ve Edebiyatları" bölümünün tanımı, "tarihsel derinlik ve karşılaştırmalı metodoloji de dikkate alınarak, modern Türk toplumlarının başta dilleri olmak üzere, edebiyat tarihleri, bugünkü edebî durumları, siyasî ve kültür tarihleri, sosyo-kültürel ve ekonomik yapıları, uluslar arası ilişkileri bakımından durumları interdisipliner bir anlayış içinde öğretilmektedir" şeklinde açıklanmıştır $^{2}$. Türk edebiyatlarına yaklaşımda karşılaştırma yönteminin ve disiplinlerara- 
s1 yaklaşımın vurgulanmış olması, söz konusu bölümün yalnızca bir repertuvar hazırlamaktan öte, Türk lehçeleri ve edebiyatları arasında köprüler kurma gibi bir misyonunun olduğunu bize göstermektedir. Bu da kuşkusuz Karşılaştırmalı Edebiyat disiplini ile ilişkilendirilebilecek bir niteliktir.

Millî edebiyatın ötesine geçebilme ile gelişen karşılaştırmalı edebiyat yaklaşımında ele alınacak araştırma alanının coğrafî niteliği, genişliği, sınırları değişiklikler gösterebilmektedir. Frankofoni gibi bir tabirle, bir ülkenin resmî dilinde (Fransızca) gerçekleşen millî olmayan edebiyatlar inceleme konusu olurken, bir ülkenin resmî dilinde yazılmış olan edebiyatı dışında kalan yerli edebiyatları ele alan incelemeler de Karşılaştırmalı Edebiyatın ilgilendiği bir konudur. Bugün, Strazburg Üniversitesi, Lyon Üniversitesi, Poitiers Üniversitesi gibi birçok Fransız üniversitesi "Yabanc1 ve Bölgesel Diller, Edebiyatlar ve Medeniyetler" adını taşıyan lisans düzeyinde programlar sunmaktadır. Poitiers Üniversitesi, sunduğu program çerçevesinde, öğrencilere iki yabancı dil (İngilizce ya da İspanyolca) üzerinden bir parkur seçmelerini önermekte ve seçilen dile göre, bu dilin konuşulduğu yabancı bir ülkede eğitim amaçlı geçici ikamet imkânı sunmaktadır³. Ad1 geçen programların isminde geçen "bölgesel" ya da "yöresel" nitelemesi ile tanımlanan diller, edebiyatlar ve medeniyetler ise romantik dönemle görünürlük kazanmaya başlamış bir alan olarak, dünya edebiyatı fikrine entegre olmuştur. Hint Edebiyatı, bu bağlamda, başlı başına, "Karşılaştırmalı Edebiyat" olarak da tanımlanmaktadır (Chevrel 2016: 13). Edebiyatın bu çalışma sahası Türkiye'de daha çok Türk Dili ve Edebiyatı çatısı altında, Halkbilimi kürsüsü kapsamında değerlendirilmektedir.

Frankofoni ile bağlantılı olarak Fransa üniversitelerinde "Karşılaştırmalı Edebiyat ve Frankofoni", "Fransız Edebiyatı ve Frankofon Edebiyatlar" (Littératures française et francophones) gibi programlar öğrencilere sunulmaktadır. "Genel ve Karşılaştırmalı Edebiyat" ismi yine Fransa'da bugün yaygın bir adlandırma olarak, özellikle yüksek lisans ve doktora program kataloglarında kendine yer edinmiştir. Bunun yanında, lisans düzeyi de dâhil olmak üzere "Karş1laştırmalı Edebiyatlar" (Littératures comparées), "Fransız Edebiyatı ve Karşılaştırmalı Edebiyat" (Littérature française et comparée), "Dünya Edebiyatları"

3 Bkz. http://formations.univ-poitiers.fr/fr/index/licence-XA/licence-XA/licence-langues-litteratures-et-civilisationsetrangeres-et-regionales-1lcer-JATN1IP9.html (Erişim tarihi: 2020.02.20) 
(Littératures du monde) gibi isimlendirmeler de söz konusudur. Ancak, belirtmek gerekiyor ki, "Dünya Edebiyatları" ya da "Yabancı Edebiyatlar" gibi programların öğretim şemalarında, hangi edebiyatlar üzerine çalışma gerçekleştirileceği önceden belirlenmiştir. Örneğin, Paris 8 Üniversitesi bünyesinde sunulan "Dünya Edebiyatları" alt-programının ana aksları Anglofon Edebiyatlar, Arap Edebiyatı, Alman Edebiyatı, İspanofon Edebiyatlar ve İtalyan Edebiyatı şeklinde belirtilmiştir. Buradan da anlaşılacağı üzere, Fransa akademik sahasında, dünya ön adı ile nitelendirilen edebiyata bir sınırlandırma getirme ihtiyacı görülmüştür. Bunun nedeni, hiç şüphesiz, daha önce de değinildiği üzere, Fransa'da edebiyatları orijinal dillerinde öğretme, inceletme ve böylece, eğitimi verilen alanın diline ve edebiyatına hâkim uzmanlar yetiştirme gayesidir.

Fransa üniversitelerinde, Karşılaştırmalı Edebiyat disiplini ile ilişkili kürsülerde, yukarıda bahsedilen isim çeşitliliği söz konusu iken, Fransızca littérature comparée ifadesinin Türkçedeki birebir karşılığı olan "karşılaştırmalı edebiyat", Türkiye üniversitelerinde, bu disiplin ile ilgili olarak kurulan ilk bölümlerin de adı olmuştur. Bununla beraber, Koç Üniversitesi "İngiliz Dili ve Karşılaştırmalı Edebiyat", Galatasaray Üniversitesi ise "Karşılaştırmalı Dilbilim ve Uygulamalı Yabancı Diller" adını taşıyan lisans programlarını bünyelerinde barındırmaktadırlar. İsimleri farkl1lıklar gösterse de Türkiye ölçeğinde aktif durumda olan tüm bu bölümlerin ortak kümesini oluşturan "karşılaştırmalı" sözcügü, söz konusu edebiyat dalına yaklaşımda kullanılan ve onun en ayırt edici özelliği olarak tanımlanan karşılaştırma yöntemine gönderme yapmaktadır.

Türkiye'de "Karşılaştırmalı Edebiyat" ismi ile kurulan ilk bölüm, 1996 yılında, Bilgi Üniversitesi bünyesinde, lisans düzeyinde olmuştur. Bölümün tan1tımında, "ulusötesi bir edebiyat anlayışını temel alan Karşılaştırmalı Edebiyatın odağı 'dünya edebiyatı' ve ötesidir" ifadesi yer almaktadır'. Aynı isimle, bir devlet üniversitesi çatısı altında kurulan ilk bölüm, Eskişehir Osmangazi Üniversitesi bünyesinde ve yine lisans düzeyinde olmuştur. 2000 y1lında kurulan bölümün vizyonu, "kültürleri kendi özgün ve özgül niteliklerinden hareketle yeniden irdelemeye yardımcı olmayı ve böylece, genel ve karşılaştırmalı edebiyat çerçevesinde ‘dünya kültürü’ ve ‘dünya edebiyatı' fikrine katkıda bulunmayı hedefler” şeklinde

4 Bkz. https://www.bilgi.edu.tr/tr/akademik/sosyal-ve-beseri-bilimler-fakultesi/karsilastirmali-edebiyat/hakkinda/ (Erişim tarihi: 2020.02.20) 
açıklanmıştır5. Burada, dünya kültürüne yaklaşımda, kültürlerin kendine özgünlügünün önemi vurgulanırken, edebiyatla birlikte tüm sanat dallarının araştırma sahasına dâhil edildiği ve böylece disiplinlerarasılık yaklaşımının altının çizildiği anlaşılmaktadır.

Bir batı Avrupa coğrafyası olan İspanya'da, Karşılaştırmalı Edebiyat, ilk olarak "edebiyat kuramı" kavramı ile edebiyat eleştirisi üzerinde yoğunlaşarak kendine bir yol bulmuştur. Daha sonrasında, "Edebiyat Kuramı ve Karşılaştırmalı Edebiyat" adında bir lisans programının yasallaşması ile akademik seviyede bu iki kavram buluşturulmuştur (Cots 2014: 445). Bugün, Barselona Üniversitesi, aynı adı taşıyan bir lisans programını çatısı altında bulundurmaktadır 6 . Öte yandan, 1974'te kurulan İspanya Genel ve Karşılaştırmalı Edebiyat Topluluğu, ismindeki "genel" ve "karşılaştırmalı" ifadeleri ile bu dönemde Fransa'da da kullanım alanı bulan ve Karşılaştırmalı Edebiyatın tek başına yeterli olmadığı fikrini işaret eden terminolojik başka bir eğilimi işaret etmektedir.

Karşılaştırmalı Edebiyat ifadesinin Almancaya "Karşılaştırmalı Edebiyat Bilimi” olarak geçtiği Almanya'da, bugün, Freiburg Üniversitesi, yüksek lisans ve doktora seviyelerinde "Genel ve Karşılaştırmalı Edebiyat Bilimi” programları sunmaktadır. Burada, yüksek lisans programında ikidilli (Fransızca ve Almanca) bir öğretim planı mevcutken, doktora programı "Edebiyat Kuramı", "Poetik, Tarihsel ve Tematik Konular", "Disiplinlerarası ve Çapraz Çalışmalar" gibi araştırma alanlarına ayrılmıştır ${ }^{7}$. Aynı ülkede bulunan Heidelberg Üniversitesi ise "Karşılaştırmalı Almanca Çalışmaları" adı altında "karşılaştırma" ve "kültürlerarasılık" bağlamında Alman dilini, edebiyatını ve kültürünü öğretme amaçlı bir yüksek lisans programı sunmaktadır.

Yunanistan'ın Girit Üniversitesi tarafından, lisans düzeyinde sunulan "Bizans ve Modern Yunan Filolojisi” bölümü altında verilen çalışma alanlarında "Karşılaştırmalı Edebiyat" kendine yer bulmuştur'. Filoloji alanı kapsamında sunulan bu çalışma sahası, eski ve modern arasında köprü kurma durumu dolayısı ile Karşılaştırmalı Edebiyat terminolojisinde yer alan "figura" kavramını

5 Bkz. https://ke.ogu.edu.tr/Sayfa/Index/36/vizyon-ozgoru (Erişim tarihi: 2020.02.20)

6 Bkz. https://www.ub.edu/web/ub/en/estudis/oferta_formativa/graus/fitxa/L/G1011/index.html (Erişim tarihi: 2020.02.20)

7 Bkz. http://studies.unifr.ch/en/doctorat/lang/comparativeliterature (Erişim tarihi: 2020.02.20)

8 Bkz. https://www.uni-heidelberg.de/en/study/all-subjects/comparative-german-studies/comparative-german-studies-master (Erişim tarihi: 2020.02.20)

9 Bkz. http://www.philology.uoc.gr/en/department/divisions/bmgp (Erişim tarihi: 2020.02.20) 
akla getirmektedir ki bu kavram, "geçmiş ve bugün arasında bağ kurabilmek için gerekli olan tinsel ve düşünsel erke" (Apter 2006: 73) anlamına gelmektedir. Bir diğer Avrupa ülkesi Hollanda' da, Leiden Üniversitesi, yüksek lisans seviyesinde, "Edebî Çalışmalar" genel başlığı adı altında "Film ve Edebiyat Çalışmaları", "Afrika Dilleri ve Edebiyatları" gibi isimlerle karşılaştırma metoduna dayanan eğitim programları sunmaktadır ${ }^{10}$. Disiplinin varlık göstermeye başladığı ilk ülkelerden olan İsviçre'de, Cenevre Üniversitesi, geleneksel isme bağlı kalarak, "Karşılaştırmalı Edebiyat", Lausanne Üniversitesi ise edebiyat kavramına çoğulluk vurgusu yaparak, "Karşılaştırmalı Edebiyatlar" adını taşıyan lisans düzeyinde programlar aracıllğı ile alana dair öğretim gerçekleştirmektedirler. Daha yenilikçi bir perspektif ile, İskandinav ülkesi Finlandiya'da bulunan Helsinki Üniversitesi'nde sunulan "Karşılaştırmalı Edebiyat" bölümünün tanıtım sayfasında, geleneksel Karşılaştırmalı Edebiyat yaklaşımının "büyük Batı Avrupa dilleri” ile sınırlandırıldığı hatırlatılarak, bölüm bünyesinde gerçekleştirilecek edebiyat çalışmalarında "tarih, dil, bölge, tür" ayrıştırmasının söz konusu olmadığının altı çizilmiştir"1. Casanova ve Moretti örneklerinde olduğu gibi, edebiyatı bir dünya sistemi olarak tasarlama girişimine ters düşen bu tutum, genelleyici-indirgeyici eğilimlerin söz konusu sahada yeri olmadığı mesajını açık bir şekilde verme ihtiyacı duymuştur.

Asya ülkesi Kore'de, yirminci yüzyılın ilk yarısında ortaya çıkan "Yeni Edebiyat" ismi ile tanımlanan ve modernleşme ekseni üzerinden ilerleyen edebiyata yeni bakış çerçevesinde "Karşılaştırmalı Edebiyat" ismi telaffuz edilmiştir (Chung 2017: 145). 1959'da kurulan Kore Karşılaştırmalı Edebiyat Topluluğu, yabancı edebiyata ilgi ve modernleşme ile özetlenebilecek bu eğilimin kurumsal hâle bürünmüş bir uzantısıdır. Bugün, Güney Kore'nin Seul kentinde bulunan Seul Ulusal Üniversitesi bünyesinde, "Disiplinlerarası Programlar" kürsüsü altında yer alan "Karşılaştırmalı Edebiyat" adını taşıyan bir lisans programı sunulmaktadır. Programın tanıtımında "disiplinlerarası çalışma" vurgusu yapılmakta ve programın amacının hem uluslararasılığa ivme kazandırmak hem de edebiyat ve film, televizyon, görsel sanatlar gibi diğer disiplinler arasında daha "yenilikçi beklentileri karşılamak" olduğu ifade edilmiştir ${ }^{12}$. Disiplinlerarasılık ve Karşılaş-

10 Bkz. https://www.universiteitleiden.nl/en/education/study-programmes/master/literary-studies-research (Erişim tarihi: 2020.02.20)

11 Bkz. https://www.helsinki.fi/en/faculty-of-arts/research/disciplines/philosophy-history-and-art/comparative-literature (Erişim tarihi: 2020.02.20)

12 Bkz. http://humanities.snu.ac.kr/en/Comparative_Literature_Introduction (Erişim tarihi: 2020.02.21) 
tırmalı Edebiyatın birlikte ele alındığı bir diğer Asya ülkesi Japonya'da, Tokyo Üniversitesi, "Disiplinler Arası Kültürel Çalışmalar" adı altında "Karşılaştırmalı Edebiyat ve Kültür" programı sunmaktadır. Programın dört ana araştırma kolu "Karşılaştırmalı Edebiyat", "Karşılaştırmalı Düşün", "Karşılaştırmalı Sanat" ve "Karşılaştırmalı Japonca Çalışmaları" isimleri altında sınıflandırılmıştır'13. Dil ve bölge sınırlaması ötesinde, felsefe, sanat, tarih, edebiyat ve müzik gibi birçok disiplin üzerine çalışma imkânı sunan bölümün, "Karşılaştırmalı Edebiyat" ve "Kültür" şeklinde iki terimi aynı isimde buluşturması ve edebiyatı, kültür gibi oldukça geniş kapsamı olan bir olgu üzerinden değerlendirmesi, bir genel edebiyat eğiliminin varlığına işaret etmektedir. Bu aynı zamanda, kültür kavramı üzerinden, edebiyatı edebiyatötesi unsurlar ile bağlantılı olarak değerlendirme tutumunu gösterir. Nitekim, "kültürel çalışmalar", Moretti'nin ortaya attı̆̆ "mesafeli okuma" ile de beraber anılan, tarihsel ve coğrafî anlamda geniş kapsamlı bir sahayı işaret eder ki Tokyo Üniversitesi örneği, yöntem olarak karşılaştırmanın, edebiyatın önüne geçtiği bir pozisyonu da bize göstermektedir.

Bir başka Asya ülkesi olan, dünya edebiyatı teriminin ilk kullanımının 1898'e dayandırıldığı (D’haen 2012: 169), yirminci yüzyılın sonlarına doğru, "kültürler arası çalışmalar" (cross-cultural studies) terimi ile Avrupa-merkezci yaklaşıma alternatif olarak, tüm kültürlere eşit yaklaşan bir araştırma sahasının ortaya çıktığı Çin'de, bugün, Pekin Normal Üniversitesi, "Çin Dili ve Edebiyatı" adını taşıyan yükseköğretim okulu bünyesindeki araştırma enstitüsü için "Karş1laştırmalı Edebiyat ve Dünya Edebiyatı” şeklinde iki kavramdan meydana gelen bir isimlendirmeye giderken ${ }^{14}$; Hong Kong Özel İdarî Bölgesinde yer alan Hong Kong Üniversitesi, lisans, yüksek lisans ve doktora seviyelerinde eğitim sunan bölümleri için "Karşılaştırmalı Edebiyat" ismiyle yetinmiştir ${ }^{15}$. Son Uluslararası Karşılaştırmalı Edebiyat Birliği (ICLA) konferansının gerçekleştiği Makau Özel İdarî Bölgesinde bulunan Makau Üniversitesi ise, lisans düzeyinde "İngilizce Çalışmaları", "Portekizce Çalışmaları" gibi daha dar tuttuğu edebiyat programlarını, yüksek lisans düzeyinde "Portekizce ve Kültürlerarası Çalışmalar" şeklinde biraz daha genişletip, doktora düzeyine gelindiğinde Çince ve İngilizce dillerinde sunduğu "Edebî Çalışmalar" ya da Portekizce dilinde sunduğu "Edebî ve Kül-

13 Bkz. http://www.c.u-tokyo.ac.jp/eng_site/info/academics/grad/ics/c/ (Erişim tarihi: 2020.02.21)

14 Bkz. https://english.bnu.edu.cn/schoolsdepartments/byx/113288.htm (Erişim tarihi: 2020.02.21)

15 Bkz. https://www.complit.hku.hk (Erişim tarihi: 2020.02.21) 
türel Çalışmalar” olarak, global bir perspektife taşımaktadır ${ }^{16}$. Görüldüğü üzere, Makau'da, Karşılaştırmalı Edebiyat, tek bir dil çerçevesinde edinilen lisans düzeyinde eğitimin, başka kültürleri de içerisine alacak biçimde, daha geniş kapsamlı bir şekilde lisansüstü düzeyde devam etmesiyle gerçekleşmektedir. Burada, tarihsel ve kültürel bağından dolayı bölgenin resmî dillerinden olan Portekizce ve Çince ile birlikte, yine bölgede varlık gösteren bir diğer önemli dil olan İngilizce'ye eğitim şemasında geniş şekilde yer veren Makau Üniversitesi, Karşılaştırmalı Edebiyat ile ilişkilendirilebilecek çokdillilik durumunun akademik yansımasına güçlü bir örnektir.

Çokdillilik olgusunun varlık gösterdiği ülkelerden bir diğeri olan Hindistan'da bulunan Delhi Üniversitesinde, "Karşılaştırmalı Hint Edebiyatı" adını taşıyan yüksek lisans programı, "Hint Dili ve Edebiyatı Çalışmaları" lisans programının uzantısı olarak karşımıza çıkarken ${ }^{17}$; Banaras Hindu Üniversitesinde, "Karşılaştırmalı Edebiyat", Nepal, Tamil ve Kannada dillerinden oluşan "Hint Dilleri" bölümü çatısı altında bir yan program olarak kendine yer bulmuştur ${ }^{18}$. Adı geçen bölümler, aynı ülke sınırları içerisinde konuşulan farklı diller üzerinden, karşılaştırmalı yöntem kullanılarak, akademik çalışmalara imkân vermektedirler. Bir başka Asya ülkesi Vietnam'ın Hanoi kentinde bulunan Ulusal Vietnam Üniversitesi ise doktora seviyesinde "Karşılaştırmalı Dilbilim”, “Az Konuşulan Vietnam Dilleri”, "Edebiyat Kuramı" programları sunmaktadır ${ }^{19}$. Hindistan örneğinde olduğu gibi, Vietnam'da da, aynı ülke sınırları içerisinde konuşulan diller, karşılaştırmalı edebiyat çalışmalarına şekil verebilmektedir. Vietnam örneği, “az konuşulan diller” üzerine akademik çalışmalar aracılığıyla, ülkenin çeşitlilik gösteren ve kendine geniş bir ifade edilme alanı bulamayan dil unsurlarını canlı tutmak adına bir farkındalık yaratma gayesi ile göze çarpmaktadır.

Asya'daki kültür ve çokdillilik yaklaşımlarından farklı olarak, Güney Amerika kıtası ülkesi Brezilya'nın Sao Paulo şehrinde bulunan Sao Paulo Üniversitesi, Fransa ve İspanya' daki geleneksel yaklaşımları hatırlatacak şekilde, kuramsallık ve eleştirellik perspektifi ile "Edebiyat Kuramı ve Karşılaştırmalı Edebiyat" adını taşıyan yüksek lisans ve doktora seviyelerinde programlar sunmaktadır.

16 Bkz. https://fah.um.edu.mo/programmes-offered/ (Erişim tarihi: 2020.02.21)

17 Bkz. http://www.du.ac.in/du/index.php?page=m-a-comparative-indian-literarture (Erişim tarihi: 2020.02.21)

18 Bkz. http://www.bhu.ac.in/arts/indian_lang/faculty.php (Erişim tarihi: 2020.02.21)

19 Bkz. https://vnu.edu.vn/eng/?C2246/N12713/University-of-Social-Sciences-\&-Humanities-(VNU-USSH).htm (Erişim tarihi: 2020.02.21) 
Programın beş araştırma alanı şu şekildedir: "Edebiyat ve Toplum", "Edebiyatta Karşılaştırmalı Çalışmalar", "Edebî Formlar ve Türler”, "Edebiyat Tarihi ve Eleştiri”, "Edebiyat ve Psikanaliz"20. Kuramsallık noktasından hareketle edebiyatı ele alan bir diğer Güney Amerika ülkesi Şili'nin Santiago de Chile kentinde bulunan Şili Üniversitesi bünyesinde, "Dilbilim ve Edebiyat" adlı lisans programı kapsaminda "Genel Edebiyat", "Edebiyat Kuramı", "İspanyol Edebiyatı", "Latinamerikan Edebiyatı" dersleri verilmektedir ${ }^{21}$. Aynı üniversitede, doktora düzeyinde "Şili ve İspanoamerikan Edebiyatı" programı sunulmaktadır. Bu aşamada, "Karş1laştırmalı Edebiyat", "Edebiyat Tarihi”, "Yöntembilim ve Estetik” gibi araştırma alanları göze çarpmaktadır. Bir başka deyişle, Şili örneği, edebiyat kavramını tarihsel ve yöntemsel açıdan değerlendiren bir eğitim ve araştırma eğilime işaret etmektedir. Öte yandan, tarihsel bağdan ötürü İspanyol Edebiyat1, coğrafî bağdan dolayı da İspanoamerikan Edebiyatı şeklinde sunulan iki araştırma sahası barındırması, üniversitenin, İspanyolcanın konuşulduğu farklı edebiyatları akademik platformda buluşturma girişimi olarak yorumlanabilir.

Edebiyat tarihi ya da edebiyat kuramı gibi geleneksel yaklaşımlardan farklı olarak, Karşılaştırmalı Edebiyatın daha modern bir bileşeni olan disiplinlerarasılık, Kuzey Amerika ülkesi Kanada'da karşımıza çıkmaktadır. Burada bulunan Montreal Üniversitesi, "Karşılaştırmalı Edebiyat”, "Sinema Çalışmaları ve Karş1laştırmalı Edebiyat", "Karşılaştırmalı Edebiyat ve Felsefe" gibi lisans programlarını öğretim kataloğunda bulundurmaktadır ${ }^{22}$. Bununla beraber, bir başka Kanada üniversitesi olan Sherbrooke Üniversitesi, mesafeli okuma yaklaşımı ile bağdaştırılabilecek "Edebî ve Kültürel Çalışmalar" adı ile lisans düzeyinde öğretim vermektedir ${ }^{23}$. Karşılaştırmalı Edebiyatın bir disiplin olarak uzun süreden beridir kendine yer edindiği ve Yeni Karşılaştırmalı Edebiyat olarak nitelendirilen terimi meydana getiren dinamiklerin olgunlaşma alanı bulduğu Kuzey Amerika kıtası ülkesi Amerika Birleşik Devletleri’nde bulunan Columbia Üniversitesi, "İngilizce ve Karşılaştırmalı Edebiyat” adını taşıyan bir bölüme sahiptir. Harvard Üniversitesi, "Karşılaştırmalı Edebiyat" adlı bir bölümü çatısı altında barındırırken, Dart-

$20 \mathrm{Bkz} . \mathrm{http} / /$ www.prpg.usp.br/index.php/en/enrolling-at-usp/list-of-courses/509-literary-theory-and-comparative-literature (Erişim tarihi: 2020.02.21)

21 Bkz. https://www.uchile.cl/carreras/5005/licenciatura-en-linguistica-y-literatura (Erişim tarihi: 2020.02.21)

22 Bkz. https://llm.umontreal.ca/programmes-cours/litterature-comparee/ (Erişim tarihi: 2020.02.21)

23 Bkz. https://www.usherbrooke.ca/admission/programme/262/baccalaureat-en-etudes-litteraires-et-culturelles/ (Erişim tarihi: 2020.02.21) 
mouth College gibi birçok Amerikan üniversitesi de yine sadece "Karşılaştırmalı Edebiyat" adını taşıyan programlar sunmaktadırlar. Bu durum, Karşılaştırmalı Edebiyatın, yirminci yüzyıldan itibaren en aktif biçimde akademik varlık gösterdiği yerlerden biri olan Amerika Birleşik Devletleri'nde, kavramın ilk hâli ile muhafaza edilmeye devam ettiğini gösteren örneklerdir.

Güney Afrika'nın Johannesburg kentinde bulunan Witwatersrand Üniversitesi, "Afrika Edebiyatı" adı ile sunduğu lisans programı ile misyonunun, Güney Afrika'nın dünyanın kalanı ile olan bağının daha güçlü hâle geldiği bir dönemde, değişen Güney Afrika ve yine durmaksızın bir değiş̧im içerisinde olan küresel edebiyat ve küresel kültüre dair dinamik bir resim ve elverişli bir bilgi aktarım ortamı sunmak olduğu ifade edilmiştir ${ }^{24}$. Küresel olarak nitelenen edebiyat ve kültürün, Güney Afrika ile bağ kurmak kaydı ile dinamik ve yenilikçi bir bakış açısı ile ele alınması, bir sınır belirleme eğilimini göstermektedir. Bundan farklı olarak, Pasifik ülkesi Yeni Zelanda'da bulunan ve Karşılaştırmalı Edebiyat tarihinin önemli isimlerinden olan Hutcheson Posnett'in de öğretim üyeliği yapmış olduğu Auckland Üniversitesi, "Karşılaştırmalı Edebiyat" adı taşıyan lisans ve doktora düzeyinde, daha geniş kapsamlı çalışmalara imkân veren programlar sunmaktadır. Karşılaştırmalı Edebiyatı "birbirinden farklı kronolojik dönemler ve disiplinler arasında, ulusal ve kültürel sınırlar ötesinde" ${ }^{25}$ bir araştırma sahası olarak tanımlayan bölüm, Posnett'in de savunuculuğunu yaptığı genel edebiyat yaklaşımından yana konum aldığını gözler önüne sermektedir.

Yukarıda yer verilen üniversitelerin çatısı altında, Karşılaştırmalı Edebiyat disiplini ile ilgili sunulan bölümlerin ya da programların adlarında ya da içeriklerinde fark edilebileceği gibi, öne çıkan bazı kavramlar, "kültür", "kültürlerarasılık", "disiplinlerarasılık", "dil çalı̧̧maları" şeklindedir. Her bir ülkedeki dinamiklerin farklılığı, küresel karakteri artık daha ağır basan dünya şartlarında, edebiyata yaklaşımda yeni yöntemlerin benimsenmesinin ve böylelikle bu beşerî bilimin zamanın şartlarına ayak uyduracak hatta onun ötesine geçebilecek yeniliklere sahip olabilmesinin önünü açmaktadır. Bu anlamda, on dokuzuncu yüzyılda, değişen dünyanın millî edebiyatın sınırlarını aşmak gereksinimini doğurduğu fikrinden hareketle, millî edebiyata alternatif olarak görülebilecek dünya

$24 \mathrm{Bkz}$. https://www.wits.ac.za/course-finder/undergraduate/humanities/african-literature/ (Erişim tarihi: 2020.02.21) 25 Bkz. https://www.auckland.ac.nz/en/study/study-options/find-a-study-option/comparative-literature.html (Erişim tarihi: 2020.02.21) 
edebiyatı kavramının muğlak tanımıyla şekillenmeye başlayan Karşılaştırmalı Edebiyat, akademik düzlemde geçmişte olduğu gibi bugün de geniş bir ad çeşitliliği göstermektedir. Burada dikkate değer olan şey, bu farklı adların içeriklerinin tümünün aslında bir ihtiyacı karşılıyor olduğudur. $\mathrm{Bu}$ da dünya edebiyatı fikrinin gerçekleşmekte olduğunu bize göstermektedir. Nitekim söz konusu kavramın standart bir tanıma indirgenmesi özüne ters düşecektir. Dolayısıyla, Karşılaştırmalı Edebiyat, kavramsal esnekliği gereği, akademik kürsülere kendi sınırlarını tayin etme özgürlügünü de beraberinde getirmektedir.

\section{Sonuç}

Dünya edebiyatı fikrini gerçekleştirmek adına, ilk olarak bir doğabilim dalı tarafindan kullanılan bir yöntemi kendine uyarlayarak bilimsel bir alan olma yolunda gelişen Karşılaştırmalı Edebiyat, bugün her ülkede birbirinden farklı isimler altında akademik varlığını sürdürmektedir. Nitekim millı̂ edebiyatın ötesine geçişte değişiklikler gösteren bakış açıları, tüm bu farklı adlandırmaları geçerli kılmakta ve dünya edebiyatı fikri ile bağdaşmaktadır. Öyle ki akademik geçmiş ve bugün bize göstermektedir ki Karşılaştırmalı Edebiyata mevcut dinamizmini veren, bir anlamda bu perspektif çeşitliliğidir. Burada, Karşılaştırmalı Edebiyat, s1nıra ihtiyaç duyan bir disiplin olmaktan ziyade, olabildiğince kapsayıcı ve günün ihtiyaçlarına da ayak uydurmayı başarabilmeyi amaç edinen, disiplinler ve sanatlar arasında köprü vazifesi gören bir işlev yüklenmektedir. Nitekim günümüzdeki akademik eğilimler, dünyanın yeni şartlarına ayak uydurma amacı ile her türlü ifade biçimini araştırma konusu yapma, kültür birliktelikleri gerçekleştirmek adına farklı coğrafyalar ya da topluluklar arasında köprüler kurma, dil varlıklarını, belli yöntemsel yaklaşımları esas alarak, başka diller ile beraber inceleme suretiyle canlı tutma şeklinde kendini göstermektedir.

$\mathrm{Bu}$ yazıda konu edinilen isim çeşitliliği ya da karmaşası, adı ne olursa olsun, Karşılaştırmalı Edebiyat yaygın adıyla bilinen ve en önemli özelliği, dünya edebiyatını gerçekleştirme ideali ile edebiyatlara karşılaştırma yöntemi aracı11ğıyla yaklaşmak olan disiplinin bugün hâlen sabit bir zemini olmadığı anlamına da gelmektedir. Nitekim Karşılaştırmalı Edebiyata temel teşkil eden fikir kabul edilen dünya edebiyatı kavramı ile kastedilenin ne olduğunun sabit bir tanımının da olmadığı ortadadır. Dil ve kültür gibi bazen millî sınırların ötesine taşabilen 
unsurların varlığından ötürü millı̂ edebiyatın bile bugün çok kolay bir kavram olmadığ düşünülür ise dünya edebiyatı fikrini kendine başlangıç kabul eden Karşılaştırmalı Edebiyat disiplininin sınırlarını belirleyebilmek, bir hayli güç bir görev anlamina gelmektedir.

Goethe'den ödünç alınan dünya edebiyatı kavramını anlamaya ve anlatmaya çalışan her fikir ve girişim aslında genel anlamıyla insanı, ülkeyi, ülkeleri, dili ve dilleri, kültürü ve kültürleri, sanatı ve sanatları, millî edebiyatları daha iyi irdelemeye, keşfedilmemiş yanlarını görmeye, humanitas kavramına daha fazla yaklaşmaya katkı sağlamaktadır. Bundan dolayıdır ki evrensellik, milletlerin kardeşliği ya da komşuluğu, yabancı veya diğer olanı tanımaya çalışma ve kendini zenginleştirme gibi ideallerden beslenen ve Karşılaştırmalı Edebiyat yaygın ismiyle anılan disiplin, bugün ne derece karmaşı ve kırılgan bir yapı gibi dursa da edebiyatın daha kapsayıcı, daha enerjik, daha yenilikçi, daha açık ve daha eleştirel bir bilim alanı olmasına yönelik bir amaca hizmet etmektedir. Nitekim birbirinden soyut ele alınan millî edebiyatlardan ibaret bir edebiyatın imkânsızlığı bugün açıktır.

Gelişimlerini tamamlamış diğer sosyal bilim dallarının aksine, edebiyat için hâlen özü arayış söz konusudur. Bu noktada, parçalı bir resim gibi görünen ve edebiyat üst başlığında değerlendirilebilecek dile ve edebiyata dair disiplinlerin, tüm edebiyatların ve kültürlerin söz sahibi olabildiği bir tartışma ve tanımlama sürecinden sonra özünü bulacağı ileri sürülebilir. Bunun gerçekleşmesine en büyük katkıyı, bu edebiyatlara görünürlük kazandıran, onlar arasında köprüler kurmayı amaç edinen akademik kürsüler sağlamaktadır. Her ifade biçiminin, etkileşim ortamı içerisinde, bir "edebiyatlar cumhuriyeti” meydana getirecek şekilde kendine yer edinebilmesi ve böylelikle, edebiyatın daha "gezegensel" bir niteliğe kavuşması ile "edebiyat", evrensel niteliğini kazanmaya daha fazla yakınlaşabilir. Bu bağlamda, yeni durumları tanımlamak adına önerilen ya da üretilen yeni adlandırmaları, edebiyatın evrenselleşme sürecine dair olağan bir sonuç olarak görmek, karşılaştırmalı edebiyat yaklaşımı ile ivme kazanan yeni durumu daha iyi irdelemek adına yerinde bir tutum olacaktır. 


\section{Kaynaklar}

Apter, Emily (2006), The Translation Zone: A New Comparative Literature, Oxfordshire: Princeton University Press.

Apter, Emily (2013), Against World Literature: On The Politics of Untranslatability, Cornwall: Verso.

Behdad, Ali \& Thomas, Dominic (2011), A Companion to Comparative Literature, West Sussex: Wiley Blackwell.

Brunel, Pierre \& Pichois, Claude \& Rousseau, A. M. (2009), Qu'est-ce que la littérature comparée?, Paris: Armand Colin.

Chevrel, Yves (2016), La littérature comparée, Paris: Presses Universitaires de France.

Chung, Ji Yong (2017), "La littérature comparée en Corée du Sud: évolution historique et état actuel”, Revue de Littérature comparée, 2-2017, 145-153.

Cots, Montserrat (2014), "Littérature comparée en Espagne : hier et aujourd'hui". Revue de Littérature comparée, 4-2014, 445-453.

Damrosch, David (2014), World Literature in Theory, West Sussex: Wiley Blackwell.

D'haen, Theo (2012), The Routledge Concise History of World Literature, Abingdon: Routledge.

D'haen, Theo \& Dominguez Cesar \& Thomsen, Mads Rosendahl (2013), World Literature: A Reader, Oxon: Routledge.

Franco, Bernard (2016), La Littérature comparée. Malakoff: Armand Colin.

Küpper, Joachim (2013), Approaches to World Literature, Akademie Verlag.

Marti Monteverde, Antoni (2017), "Edgar Quinet, Joseph Texte et les origines de la Littérature Comparée à Lyon”, Revue de Littérature comparée, 3-2017, 291-305.

Meriç, Cemil (2017), Kırk Ambar: Rümuz-ül Edeb, İstanbul: İletişim Yayınları.

Moore, Stephen D. \& Rivera, Mayra (2011), Planetary Loves: Spivak, Postcoloniality, and Theology, New York: Fordham University Press.

Pageaux, Daniel (1994), La littérature générale et comparée, Paris: Armand Colin.

Prendergast, Christopher (2004), Debating World Literature, Essex: Verso.

Sturm-Trigonakis, Elke (2013), Comparative Cultural Studies and the New Weltliteratur, Indiana: Purdue University Press. 